\title{
EL ESCRITOR EN EL MOMENTO ACTUAL
}

\author{
Dina Emeteria Chávez Bellido \\ Universidad Ricardo Palma \\ dina_chavez2006@hotmail.com
}

El compromiso real del escritor es el de crear belleza a partir de un verso, un cuento, una novela, una obra de teatro; y que todo ello envuelva al lector con un trozo de su vida soñada o vivida, sin necesariamente haber conocido al autor. El tema puede ser de belleza, de amor, de rechazo, de deleite, de estupor; pero sobre todo debe iluminar el cámac del lector y echarlo a andar después de una situación dolorosa y evitarle el abismo de un suicidio, aliviarlo de una depresión aguda, ayudarlo a salir libre de un sociópata que atentó contra su vida, sosegar al que perdió el sí de un amor o recibió el no de los desamores presentes en su psiquis y en los ojos de su alma - por un tiempo o quizá para siempre- si no reprograma su mente a través de la neurolingüística y el amor. Así, el fortalecido por la literatura podrá calzarse en el dolor del otro e investirse de la fe en Dios.

La obra del escritor busca o intenta -y casi siempre lo consiguecrear belleza en cada palabra que exhala en su obra literaria y atrapa en su telaraña estética al lector desde el comienzo hasta el final.

El escritor da inicio a ese hermoso engarzamiento de versos, de hechos, de tramas, que consciente e inconscientemente invita al lector a formar parte de esa historia. Al final la obra no solo pertenece al autor sino a cada uno de los lectores que esperan ávidos la nueva obra de su autor preferido u otro por conocer.

A través de las obras literarias conocemos la vida de los seres humanos de todos los tiempos, por supuesto confabulados con la ficción y la verdad, sus tipos de vida, sus costumbres de amar, de generar relaciones interpersonales, las diversas formas de comunicación y, sobre todo, podemos conocer su historia a través de mitos y leyendas, casi siempre 
contadas a través de la literatura oral, refranes, cuentos, dichos y toda esa cosmovisión que es el Taj Mahal de cada pueblo o cultura.

De ahí que encontramos a Matsuo Basho, escritor medieval japonés y cultor de hermosos versos llamados haikus, tan breves llenos de esencia, y que, sobre todo, expresan la contemplación intimista con la naturaleza. A Orhan Pamuk, Premio Nobel turco, quien nos quita la fantasía de un Estambul ideal con la visión de un Bósforo contaminado, igual o más que el río Rímac; de igual manera vemos a Mario Vargas Llosa, Premio Nobel quien en su obra de La fiesta del chivo nos cuenta, después de investigar 15 años, cómo fue el gobierno dictatorial dominicano.

Tenemos, así mismo, a un José María Arguedas, quien a través de todas sus obras nos hace amar y conocer la cultura andina y toda su cosmovisión, no solo él viviendo con ellos, sino utilizando la llave mágica para conocer una cultura: su lengua, el quechua. Y de César Vallejo, el segundo cantor del mundo, su compromiso total con el dolor de todo ser humano, cualquiera sea su religión, idioma o lugar de nacimiento.

También Albert Camus crea gran sensibilidad en el lector al referirse a una época que él no vivió, pero se identifica con ella y la revive dramáticamente en su obra La peste. Walter Whitman con la celebración a sí mismo con una oración hecha verso a todo Estados Unidos y extrapolando ello a cada ser humano nacido, por nacer, por morir o que ya dejó esta vida, pero que seguro vivió dos veces: una para vivir su propia vida y otra para cumplir sus sueños, a pesar de los problemas que son solo la punta de un iceberg, que asoma cada instante en la vida del ser humano, pero que no lo detiene en el camino que tiene trazado

El escritor tiene un compromiso consigo mismo y con su quehacer de creador, lo cual provoca que su obra literaria sea un deleite y goce para el lector. Pero si el texto no solo excita las neuronas, el espíritu del lector, sino también logra trascender en lo social, estaríamos hablando de una responsabilidad cumplida del autor con el tiempo, la época que le ha tocado vivir, tal como Dante, Shakespeare, Tolstoi, etc.; empero, eso escapa al compromiso del escritor, que es crear belleza y sensibilizar al lector. No cabe duda que para crear su obra artística se vale de la materia prima que es la realidad. 
En lo que respecta a Gabriel García Márquez, otro de los grandes escritores de nuestro tiempo, escribió en 1959 en la revista La calle:

Acaso sea más valioso contar honestamente lo que uno se cree capaz de contar por haberlo vivido, que contar con la misma honestidad lo que nuestra posición política nos indica que debe ser contado, aunque tengamos que inventarlo.

En noviembre de 2005 el crítico Juan Gabriel Vásquez comentó sobre el dilema de los novelistas pegados al relato testimonial y sorprendidos por la nueva forma de narración de García Márquez:

Pero el caso parece ser que éstos se dieron cuenta de que estaban en presencia de una gran novela y no tuvieron la serenidad ni la paciencia, pero ni siquiera la astucia, de tomarse el tiempo que necesitaban para aprender a escribirla. No teniendo en Colombia una tradición que continuar, tenían que empezar por el principio, y no se empieza una tradición literaria en veinticuatro horas.

Y por todo lo expresado, un poeta, un cuentista, novelista o dramaturgo no solo busca una distinción personal en la vida; debe elegir su camino, su orientación y su estilo. Si la literatura no es todo, no vale la pena perder ni un minuto en ella. Esta se muere si se sujeta a la ingenuidad, a las canciones. Si cada verso o palabra no retumba y se incuba en todos los entresijos del ser humano y de la sociedad, no significa nada.

En suma, solo un todo puede ser bello. Aunque el escritor auténtico no puede salvar al mundo $-\mathrm{y}$ a veces ni siquiera a un solo hombre, ni salvarse a sí mismo, ni ser leído por nadie-, seguirá su vocación de escribir como parte de su destino. La vida del escritor le da la posibilidad de recuperarse o exorcizarse de una experiencia que le persigue y que se convierte para él en parte de su vida y, en cierta forma, en una pesadilla. El acto de escribir se convierte en una necesidad imperiosa y en la forma más alta de la necesidad de comunicación, y así el artista de la palabra seguirá escribiendo aun por encima de sus grandes desilusiones, porque para el escritor la literatura es su máxima inversión y prioridad. 


\section{FUENTES CONSULTADAS}

Arguedas, J. (1964) Todas las sangres. Buenos Aires, Editorial Losada.

García M., G. (1967). Cien años de soledad. Buenos Aires, Editorial Sudamericana.

Gonçález Holguín, Diego (1989 [1608]) Vocabvlario de la Lengva General de todo el Perv, Lima, UNMSM.

Taylor, Gerald (1999 [1610]) Ritos y tradiciones de Huarochirí, Lima, segunda edición, Instituto de Estudios Peruanos, Instituto Francés de Estudios Andinos, Banco Central de Reserva y Universidad Particular Ricardo Palma.

Vargas Llosa, M. (2000). La fiesta del chivo. Lima, Editorial Alfaguara.

Vallejo, C. (1939). Poemas humanos. París

Vásquez, Juan Gabriel (2005) "Malentendidos alrededor de García Márquez" en Letras Libres, 5 de noviembre en

http://www.letraslibres.com/mexico-espana/malentendidos-alrededorgarcia-marquez

Whitman, W. (1865). Hojas de hierba. New Jersey, Publicación personal. 